\title{
Somatostatin Receptor Type 2b
}

National Cancer Institute

\section{Source}

National Cancer Institute. Somatostatin Receptor Type 2b. NCI Thesaurus. Code C118484.

Somatostatin receptor type $2 \mathrm{~b}$ ( $356 \mathrm{aa}, \sim 40 \mathrm{kDa}$ ) is encoded by the human SST R2 gene.

This protein plays a role in $\mathrm{G}$ protein-coupled receptor signaling. 